\title{
The Stable Isotope Method In Human Paleopathology and Nutritional Stress Analysis
}

\author{
Gabriele Scorrano* \\ Department of Biology, University of Rome Tor Vergata, Italy. \\ Natural History Museum of Denmark; University of Copenhagen, Denmark.
}

*Corresponding author: Gabriele Scorrano, Center of Molecular Anthropology for the Study of Ancient DNA, Department of Biology, University of Rome Tor Vergata, via della Ricerca Scientifica n. 1, 00173, Rome, Natural History Museum of Denmark; University of Copenhagen, Denmark. Italy

Submission: 㘹 May 10, 2017; Published: 㘹 May 10, 2018

\section{Introduction}

The use of stable isotopes to analyse the diet composition in ancient populations, calculating the carbon and nitrogen isotopic ratios detectable from the bone collagen, begun in the mid-1970s. These stable isotopes are useful in diet reconstruction, because the food sources are isotopically distinct and hence, they are well established indicators of the main dietary sources consumed by an individual over his life-span. Moreover, in the last few years the isotopic method has been also applied to modern individuals suffering from eating disorders or nutritional stress, underscoring the relevance of an isotopic fractionation change occurring under these conditions. The biochemical mechanisms related to starvation or nutritional stress complicate the interpretation of the results from isotopic data in ancient bones remains, where it is not possible to use medical information for the samples analysed. Then, the aim of the present mini-review is to propose a correct analytical workflow for anthropological analyses.

Molecular analyses of ancient remains has help edarchaeoanthropological research by contributing to shed light on some yet unsolved issues, like get a better understanding about the ecological, demographic, and genetic history of ancient communities and in the study of the paleo-diets. Molecular analysis was first applied to a diet study by Vogeland van der Merwe [1,2], in themid-1970s, when they began exploring stable isotopes as a way to infer the diet in ancient populations. The method is based on calculating the ${ }^{13} \mathrm{C} /{ }^{12} \mathrm{C}$ and ${ }^{15} \mathrm{~N} /{ }^{14} \mathrm{~N}$ isotopic ratios that are detectable from the bone collagen and can reveal the last 10 to 15 years of the subject's diet [3]. This analysis is useful in diet reconstruction, because the food sources are isotopically distinct, due to the isotopic fractionation that occurs in metabolic processes [4]. In mathematical terms, the ratio of these isotopes is expressed in notation $\delta: \delta^{13} \mathrm{C}$ and $\delta^{15} \mathrm{~N}$ and is equal to the difference between the isotopic ratios of the sample relative to a reference standard (Pee Dee belemnite for the carbon and atmospheric nitrogen for the nitrogen), calculated in parts per thousand $[5,6]$. The $\delta^{13} \mathrm{C}$ study is particularly appropriate to discriminate between terrestrial and marine food consumption, as well as for plants with different photosynthetic pathways ( $\mathrm{C} 3$ and $\mathrm{C} 4$ ). The $\delta^{15} \mathrm{~N}$ ratio is useful to understand the tropic level of the samples analysed, because a growth of $3-5 \%$ is observed along the trophic chain [7].

The diet analysis in early hominins is an important topic when studying human evolution and has been developed in several papers in which ancient remains (such as Australopithecus and Paranthropus) have been successfully analysed [8]. Variations in dietary strategies have been also tracked from the earliest species of Homo, who showed primitive nutritional patterns via archaic technologies, as well as to Neanderthals [9]. Similarly, dietary change modifications continued throughout more recent periods, such as when animal husbandry and agriculture have been first developed during the Neolithic Revolution $[10,11]$. In historical periods, diet analysis helped to also clarify whether differences in nutritional composition relate to the gender, age or social status of individuals.

In recent years, a few authors have applied the isotopic method to evaluate carbon and nitrogen values in contemporary living individuals suffering from eating disorders or in those individuals facing nutritional stress. For example, Mekota et al. [12] analysed patients affected with anorexia nervosa and detected an inverse correlation of the carbon and nitrogen stable isotope ratio with the Body Max Index (BMI). Also, Fuller et al. [13] studied samples under nutritional stress and observed an increase in stable isotopic ratio values during periods of weight loss. These approaches show how the isotopic method may also reflect not only dietary but also individual health and nutritional status. Indeed, isotopic variation scan be attributed to the stable isotope fractionation change that occurs during times of starvation and metabolic disease [12,14,15]. At the times, the $\delta^{15} \mathrm{~N}$ value derives from the catabolism process, particularly from gluconeogenesis, where non-carbohydrate sources produce glucose [16]. In this way, the nitrogen source is a consumer tissue, which leads to an increase in the nitrogen isotopic ratio [17-19], because the ${ }^{15} \mathrm{~N}$ has already been enriched, due to the trophic level fractionation that occurred between diet and consumer tissues (similar to breastfeeding effects) [20]. This 
biochemical catabolism also changes the $\delta^{13} \mathrm{C}$ because the use of body proteins during nutritional stress has the same trophic effect and increases $\delta^{13} \mathrm{C}$ values $[13,17,18,21]$. Moreover, additional enrichment occurred on the carbon stable isotope ratio, due to the fractionation from plant food to consumer protein [22].

These biochemical mechanisms greatly complicate the interpretation of isotopic data, especially in ancient bones remains, where it is not possible to use medical information for the samples analysed. In these situations, isotopic change due to metabolic/ nutritional stress is not easily identifiable, but nonetheless it could influence the interpretation of the results. This now well-known difficulty then is forcing us to think about how to set up a correct analytical workflow for anthropological analyses. In recent years, some authors have applied such novel and more comprehensive isotopic evaluation approach to archaeological remains. In a 2014 Nature News, for instance, Ewan Callaway [23] discussed the importance of using a multidisciplinary approach to confirm the presence of Celiac Disease in an ancient young woman: an analysis of her ancient remains aimed to correlate isotopic variations with unspecific stress markers (such as Criba orbitalia, Cribra cranii and enamel hypoplasia) often associated with mal nutritional stress periods, and genetic predisposition [24-27]. This analysis was focused around reconstructing the diet of the young woman likely suffering from Celiac Disease and highlighted the possible association with chronic malnutrition due to the disease [24].

This simple example strongly suggests that it would be critical to study the state of health of the samples analysed in order to achieve a better interpretation of the stable isotope data. This strategy could represent a novel approach when analysing ancient remains and could facilitate the identification of the presence or absence of pathological/malnutrition stress on the bones, ultimately leading to a more correct interpretation of the isotopic data. It seems then useful to more carefully investigate the diet of ancient populations to raise awareness of the presence/absence of unspecific stress markers attributable to starvation periods/ metabolic diseases. A multidisciplinary approach is therefore beneficial, especially when analysing prehistoric populations with nutritional peculiarities or deficiencies that may have affected isotopic data. In this context, the isotopic approach could also be used as a potential molecular marker of metabolic disorder or starvation in the ancient community, and could substantially contribute to identify the health status of the analysed individuals: the analysis of ancient DNA (aDNA) can then confirm whether these individuals were carrying the genetic variants that predispose to the given disease $[24,26,27]$. This approach could enrich the study of even complex diseases, such as diabetes, shedding light on its history and its evolution in our species, mostly since few ancient writers recorded or described diseases in ancient populations. One of the earliest scholars who wrote a general treatise on diseases was Aretaeus by Cappadocia (around I A.D.) who described in detail the symptoms of a large number of diseases, like Celiac disease and diabetes. Aretaeus was the first known ancient writer to describe the mal absorptive symptoms consistent with a modern diagnosis of Celiac disease [28], although he did not provide information about the diachronic prevalence of the disease.

Another advantage of using isotopic analyses in these contexts is that genetic analyses of ancient diseases are difficult to perform for three main reasons:

a) Highly degraded a DNA sequences (due to the preservation conditions) can limit the identification of the SNPs of metabolic pathways related to the pathologies.

b) Most genetic diseases are jointly caused by many genes and environmental factors and identifying a disease-related haplo type yields information about a possible predisposition to a disease but does not provide information on the manifestation of the disease on the analysed sample.

c) Finally, aDNA analysis is costly and time-intensive. Therefore, the stable isotope method is often the unique molecular method that can be efficiently used.

In conclusion, holistic analysis must to be applied to uncover more information from the bones and stable isotopic analyses should be more routinely in corporate into the analysis of past populations. A lot of information has been "written in the bones," but we have to learn how to read them better.

\section{Acknowledgement}

I am grateful to Prof. Olga Rickards and to Prof. Fabio Macciardi for them insightful and constructive comments. I thank Lindsey B. Anderson for her assistance with the English revision of the manuscript.

\section{References}

1. Vogel JC, van der Merwe NJ (1977) Isotopic evidence for early maize cultivation in New York State. American Antiquity 42: 238-242.

2. Van der Merwe NJ, Vogel JC (1978) ${ }^{13} \mathrm{C}$ Content of human collagen as a measure of prehistoric diet in woodland North America. Nature 276(5690): 815-816

3. Hedges REM, Reynard LM (2007) Nitrogen isotopes and the trophic level of humans in archaeology. Journal of Archaeological Science 34(8): 1240-1251.

4. DeNiro MJ (1985) Postmortem preservation and alteration of in vivo bone collagen isotope ratios in relation to palaeodietary reconstruction. Nature 317(6040): 806-809.

5. Richards MP, Shulting RJ, Hedges REM (2003) Sharp shift in diet at onset of Neolithic. Nature 425(6956): 366.

6. Giorgi F, Bartoli F, Iacumin P, Mallegni F (2005) Oligoelements and isotopic geochemistry: a multidisciplinary approach to the reconstruction of the paleodiet. Human Evolution 20(1): 55-82.

7. Tykot RH (2004) Stable isotopes and diet: You are what you eat. Proceedings of the International School of Physics "Enrico Fermi" Course CLIV, Martini M, Milazzo M , Piacentini M, (Eds.), IOS Press, Amsterdam, Holland.

8. Sponheimer M, Alemseged Z, Cerling TE, Grine FE, Kimbel WH, Leakey MG, et al. (2013) Isotopic evidence of early hominin diets. PNAS 110(26): 10513-10518. 
9. Richards MP, Trinkaus E (2009) Isotopic evidence for the diets of European Neanderthals and early modern humans. PNAS 106(38): $16034-16039$

10. Lelli R, Allen R, Biondi G, Calattini M, Barbaro CC, et al. (2012) Examining dietary variability of the earliest farmers of south-eastern Italy. Am J Phys Anthropol 149(3): 380-390.

11. Craig OE, Biazzo M, Colonese AC, Di Giuseppe Z, Martínez-Labarga C, et al. (2010) Stable isotope analysis of Late Upper Palaeolithic human and faunal remains from Grotta del Romito (Cosenza), Italy. Journal of Archaeological Science 37(10): 2504-2512.

12. Mekota AM, Grupe G, Ufer S, Cuntz U (2006) Serial analysis of stable nitrogen and carbon isotopes in hair: monitoring starvation and recovery phases of patients suffering from anorexia nervosa. Rapid Commun Mass Spectrom 20(10): 1604-1610.

13. Fuller BT, Fuller JL, Sage NE, Harris DA, O'Connell TC, et al. (2005) Nitrogen balance and delta15N: why you're not what you eat during nutritional stress. Rapid Commun Mass Spectrom 19(18): 2497-2506.

14. Katzenberg MA, Lovell NC (1999) Stable Isotope Variation in Pathological Bone. Int J Osteoarchaeol 9: 316-324.

15. Olsen KC, White CD, Longstaffe FJ, von Heyking K, McGlynn G, et al. (2014) Intraskeletal isotopic compositions $\left(\delta^{13} \mathrm{C}, \delta^{15} \mathrm{~N}\right)$ of bone collagen: nonpathological and pathological variation. Am J Phys Anthropol 153(4): 598-604

16. Voet D, Voet J (1995). Biochemistry (2nd edn.) John Wiley, New York, USA.

17. Hobson KA, Clark RG (1992) Assessing avian diets using stable isotopes II: factors influencing diet-tissue fractionation. The Condor 94(1): 189197.

18. Hobson KA, Alisauskas RT, Clark RG (1993) Stable nitrogen isotope enrichment in avian tissues due to fasting and nutritional stress implication for isotopic analyses of diet. The Condor 95(2): 388-394.

19. Gannes LZ, O’Brien DM, del Rio CM (1997) Stable isotopes in animal ecology: assumptions, caveats, and a call for more laboratory experiments. Ecology 78(4): 1271-1276.
20. Fogel ML, Tuross N, Owsley DW (1989) Nitrogen isotope tracers of human lactation in modern and archeological populations. Annual Report of the Director of the Geophysical Laboratory, Carnegie Instn Washington, 1988-1989. DC: Geophysical Laboratory, Washington, USA, pp. 111-117.

21. Fuller BT, Fuller JL, Sage NE, Harris DA, O'Connell TC, et al. (2004) Nitrogen balance and $\delta^{15} \mathrm{~N}$ : why you're not what you eat during pregnancy. Rapid Commun Mass Spectrom 18: 2889-2896.

22. Lee-Thorp JA, Sealy JC, van der Merwe NJ (1989) Stable carbon ratio differences between bone collagen and bone apatite, and their relationship to diet. Journal of Archaeological Science 16(6): 585-599.

23. Callaway E (2014). Ancient bones show signs of struggle with coeliac disease. Nature.

24. Scorrano G, Brilli M, Martínez-Labarga C, Giustini F, Pacciani E, et al. (2014) Palaeodiet reconstruction in a woman with probable celiac disease: a stable isotope analysis of bone remains from the archaeological site of Cosa (Italy). Am J Phys Anthropol 154(3): 349-56.

25.Zarina G, Sholts SB, Tichinin A, Rudovica V, Vīksna A, et al. (2016) Cribra orbitalia as a potential indicator of childhood stress: Evidence from paleopathology, stable $\mathrm{C}, \mathrm{N}$, and $\mathrm{O}$ isotopes, and trace element concentrations in children from a 17th-18th century cemetery in Jēkabpils, Latvia. J Trace Elem Med Biol 38: 131-137.

26. Gasbarrini G, Miele L, Corazza G, Gasbarrini A (2010) When was celiac disease born?: the Italian case from the archeologic site of Cosa. J Clin Gastroenterol 44(7): 502-503.

27. Gasbarrini G, Rickards O, Martinez-Labarga C, Pacciani E, Chilleri F, et al. (2012) Origin of celiac disease: how old are predisposing haplotypes? World J Gastroenterol 18(37): 5300-5304.

28. Adams F (1856) Coeliac disease has a diverse clinical heterogeneity, and increases both morbidity and mortality. In: Adams F (Ed.), The extant works of Aretaeus the Cappadocian (edn), Boston Milford, US.
Creative Commons Attribution 4.0

International License

For possible submissions Click Here

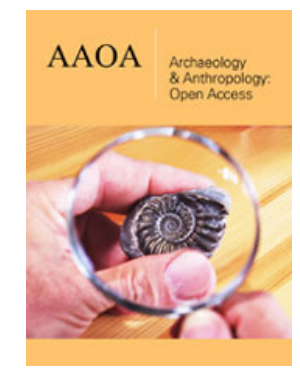

\section{Archaeology \& Anthropology: Open Access}

\section{Benefits of Publishing with us}

- High-level peer review and editorial services

- Freely accessible online immediately upon publication

- Authors retain the copyright to their work

- Licensing it under a Creative Commons license

- Visibility through different online platforms 